2. Nadas AS. Pediatric cardiology. 3rd Ed. Philadelphia : W.B. Saunders, 1973 : 44-76.

3. Keith JD, Rowe RD, Vlad P. Heart disease in infancy and childhood. 3rd Ed. New York : Macmillan, 1978

4. Moss AJ, Adam FH, Emmanouilides GC. Heart disease in infants, children and adoles- cents. 2nd Ed. Baltimore: William ạnd Wilkins, 1978

5. Hurst JW. The heart, update I. New York : McGraw Hill, 1979, 13-45

6. Braunwald E. Heart disease, a textbook of cardiovascular medicine. Philadelphia : W.B. Saunders, 1980, 198-252

\title{
CONTROVERSIES IN THE MANAGEMENT OF ACUTE IDIOPATHIC THROMBOCYTOPENIC PURPURA
}

Few disagree that bone marrow examinations should always be performed prior to steroid administration. It remains clearly unacceptable to misdiagnose leukemia as idiopathic thrombocytopenic purpura without a bone marrow examination, and then to compound the error by treating what is in reality the former disorder with steroids alone. Few disagree that intracranial hemorrhage is an indication for aggressive therapy, including steroids. Beyond these points there is contention. Forty-six per cent of hematologists prescribe steroids more than half the time, whereas $54 \%$ prescribe them less than half the time. Seven per cent always prescribe them; $7 \%$ never prescribe them. When seeing a patients with typical clinical symptoms of this disorder, $74 \%$ of specialists would perform a marrow aspiration; nevertheless, $26 \%$ would defer the procedure. However, of the $26 \%$, none implied that they might use steroid therapy at some point later in the disease without first performing a bone marrow examination. Among hematologists stating there was a specific platelet count alone that they would use to treat patients, this count varied between $1,000 / \mu \mathrm{L}$ and $50,000 / \mu \mathrm{L}$. Thus acute indiopathic thrombocytopenic purpura, a benign and self-limited disease, provides us the luxury of a flexible approach to its management. 